\title{
Eochelysipus horni, a new vertebrate trace fossil from the Tournaisian Horton Bluff Formation, Nova Scotia
}

\author{
David J. Mossman ${ }^{1^{*}}$ and Robert G. Grantham ${ }^{2 \dagger}$ \\ 1. Department of Geography, Mount Allison University, 144 Main Street, Sackville, New Brunswick E4L 1A7, Canada \\ 2. Johnson Geoscience Centre, 175 Signal Hill Road, St John's, Newfoundland A1A 1B2, Canada \\ *Corresponding author: <dmossman@mta.ca> \\ $\dagger$ Present address: 253 Club Road, Hatchet Lake, Nova Scotia B3T 1R3, Canada
}

Date received: 29 May 2006 Date accepted: 01 June 2007

\begin{abstract}
A new vertebrate trackway is described from the coastal-marine sequence at Blue Beach and Horton Bluff, Nova Scotia. Eochelysipus horni ichnogen. et ichnosp. nov., features a wide trackway, low pace angle, elongate anteriorly oriented digital scrape marks, hands slightly interior to the trackway, and five-toed hind limbs. It is probably that of a parareptile and a close ancestral form to turtles; the trackway was impressed on firm mud. Present nearby at the same stratigraphic level is a topotype of Peratodactylopus bishopi ichnogen. et ichnosp. nov., a trackway of a captorhinomorph reptile discovered here in 1974. Elsewhere at Blue Beach a large enigmatic trackway (Baropezia ichnosp.?) attests to the wide range of tetrapod morphologies present in these Tournaisian sediments. The assemblage of fossils, palaeoichnological and osteological alike, highlight the importance of this locality for revealing details of Earth's early air breathing community at the Devonian-Mississippian transition.
\end{abstract}

\section{RÉSUMÉ}

Une nouvelle piste de vertébré est décrite dans la séquence côtière-marine de la falaise Blue Beach Horton, en Nouvelle-Écosse. L’ichnogenre et ichnoespèce nouvelle Eochelysipus horni se caractérise par une piste large, un angle de train bas, des marques de frottement digital orientées vers l'avant et allongées, des mains légèrement à l'intérieur de la piste et des membres arrière à cinq orteils. Il s'agit probablement de la piste d'un parareptile et d'une forme ancestrale proche des tortues; l'animal a empreint son passage dans une boue ferme. On relève à proximité, au même niveau stratigraphique, la présence d'un topotype de l'ichnogenre et ichnoespèce nouvelle Peratodactylopus bishopi, une piste d'un reptile captorhinomorphe découvert au même endroit en 1974. Ailleurs à Blue Beach, une piste importante énigmatique (ichnoespèce Baropezia?) atteste le vaste éventail de morphologies de tétrapodes présentes dans ces sédiments du Tournaisien. L'assemblage de fossiles, tant paléoichnologiques qu'ostéologiques, met en reliefl'importance de cet emplacement pour la révélation de détails sur la première communauté atmosphérique de la terre à l'époque de la transition du Dévonien au Mississippien.

[Traduit par la redaction]

The Earth not only contains within her bosom, substances the most necessary and indispensable to supply the wants of man; but also exhibits in her vast museum, the most certain, and imperishable records of her own history, written in characters not to be mistaken by the most humble, destroyed by the most powerful, nor blotted out even by time itself. - Abraham Gesner, 1836, Remarks on the Geology and Mineralogy of Nova Scotia

\section{INTRODUCTION}

Designated the type area of the Horton Group by Bell (1929), the Horton Bluff Formation (HBF) (Fig. 1) records environmental conditions that existed for significant periods over much of the Maritimes Basin (Martel et al. 1993; Calder 1998) during the Devonian-Mississippian transition. The 215 $\mathrm{m}$-thick Blue Beach Member is the third of four members
[Harding Brook (base), Curry Brook, Blue Beach, Hind Creek (top)] of the HBF. It comprises several lagoonal/lacustrine sedimentary facies characteristic of a coastal-marine stratigraphic sequence (Tibert and Scott 1995). [This is in contrast to Bell's (1960) three gradational members of the HBF: Lower (fluvial), Middle(fluvial/lacustrine below, to overlying open lacustrine), 


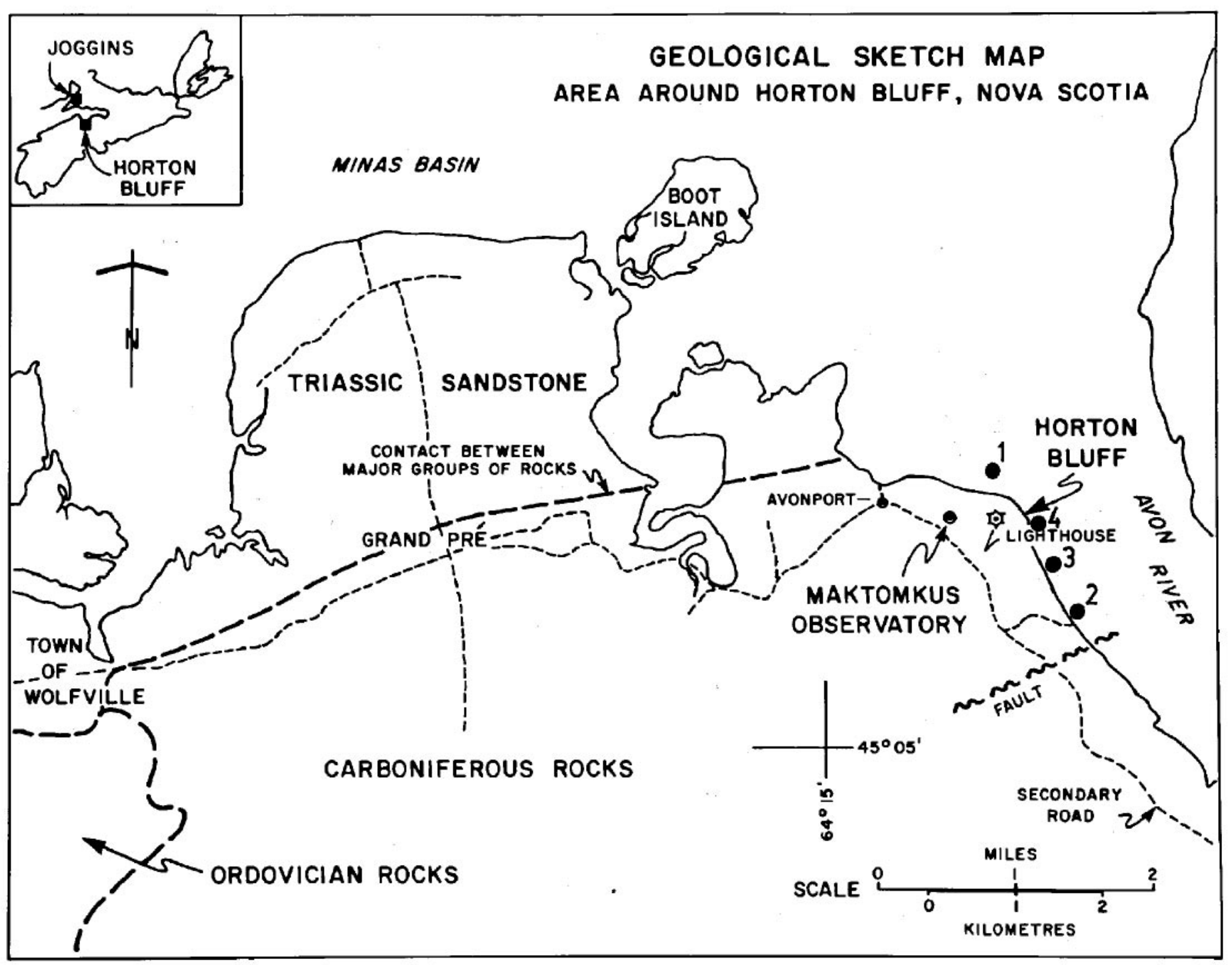

Fig. 1 Geological sketch map of the area around Horton Bluff, Nova Scotia. Localities 1 to 4 mark respectively the discovery sites of: Baropezia ichnosp.; Eochelysipus horni ichnogen. et sp. nov.; topotype of Peratodactylopus bishopi ichnogen. et ichnosp. nov.; and stump impressions of Lepidodendropsis. (Modified after Crosby 1962).

and Upper (lacustrine/deltaic)]. It has since been determined that the lowermost $7.3 \mathrm{~m}$ of the Harding Brook member is latest Devonian (Martel et al. 1993).

Results of detailed work by Martel and Gibling (1996) indicate that the water body from which the Blue Beach Member originated was linked to the ocean and experienced restricted marine conditions. Grey-blue clay shale, ostracods, disarticulated fish remains, and the relict impressions of the once vertical stumps of Tournaisian trees (Lepidodendropsis) (Fig. 2) are evident. At various levels, an abundant palaeoichnological record is likewise preserved of the earliest epoch of air breathing vertebrates (Mossman and Sarjeant 1980; Sarjeant and Mossman 1978a). A range of tetrapod morphologies is evident in the Tournaisian sediments at Horton Bluff (Clack and Carroll 2000).

The Carboniferous has been referred to as the "Age of amphibians" because of the diversity known from much of
Pangea. However it appears that the remains of reptiles are also well-represented in earliest Carboniferous strata (Sarjeant and Mossman 1978a). Indeed, the existence of terrestrial tetrapods has now been pushed back to Late Devonian on the basis of palaeoichnological evidence (Warren et al. 1986) as well as skeletal remains (Daeschler et al. 1994). The Horton Bluff fossils confirm that, with respect to tetrapod evolution, appendicular mechanisms of support and propulsion were well-developed by the Early Carboniferous. Hylonomus is still recognized as the first equivocal reptile, although it is not ancestral to all reptile lineages (Ahlberg and Milner 1994; Reisz 1997). Thus, there should be a common ancestor older than Westphalian A out there somewhere, perhaps at Horton Bluff. However, even when a complete skeleton is preserved, as in Scotland's Westlothiana from the Visean (Ahlberg and Milner 1994), a good deal of uncertainty remains. Even five toes occur in the intermediary group sometimes referred to as reptilomorphs, 


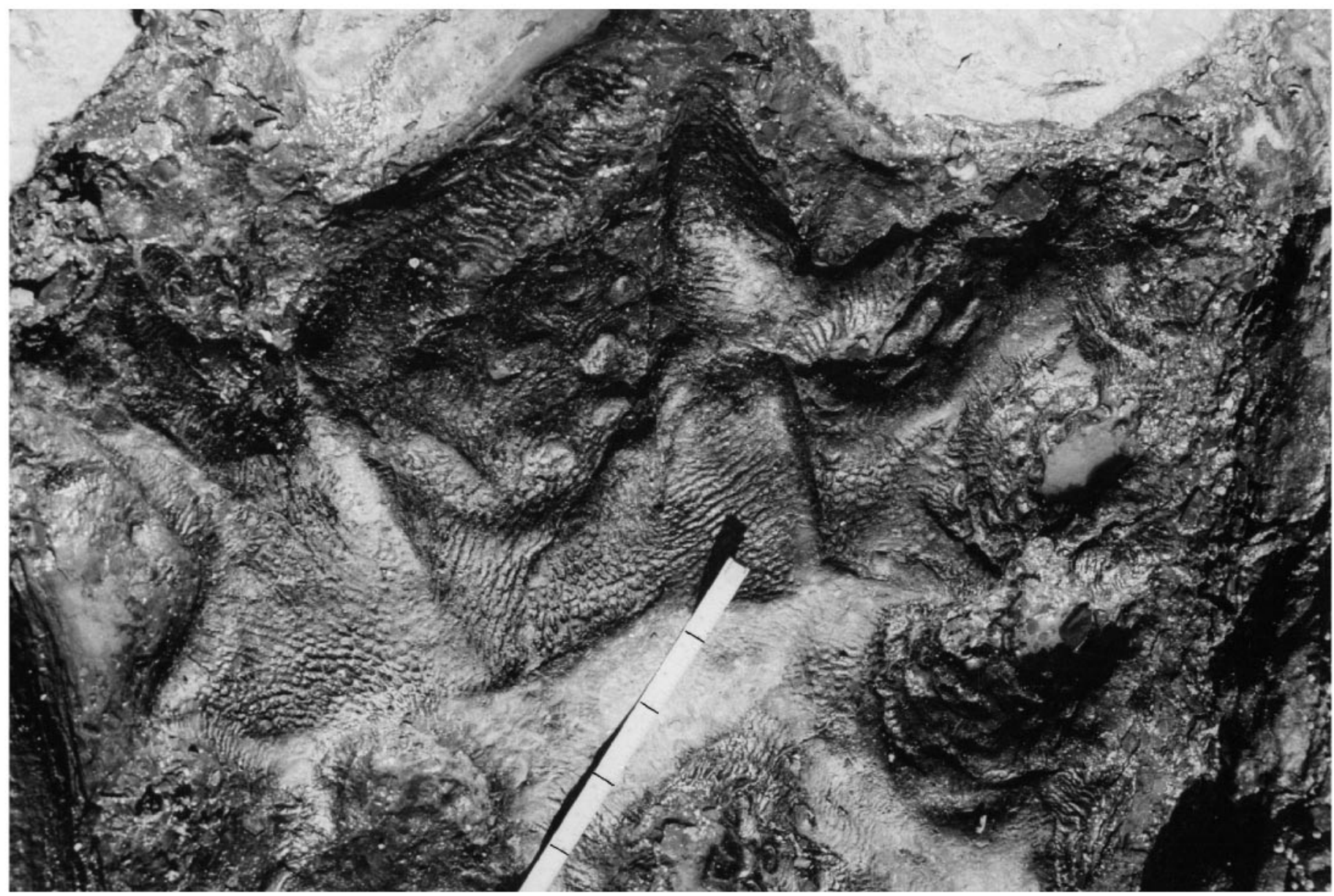

Fig. 2 One of several well preserved basal impressions of Lepidodendropsis near the discovery site of Eochelysipus horni ichnogen. et sp. Nov. These depressions are easily mistaken for footprints except that among other distinguishing features thin films of carbon line the impressions. Knife (for scale) at left is $9 \mathrm{~cm}$ long; width of impression $=40 \mathrm{~cm}$.

and which generally are considered to be tetrapods with strong reptilian affinity, but not reptiles sensu stricto.Traditionally, turtles have long been considered as the sole surviving members of anapsids, a primitive reptile subclass of basal amniote stock closely related to captorinids, which originated ca. 325 Ma ago during the early Paleozoic (Colbert 1980; Orenstein 2001). According to Reisz (1997) the fossil record provides extensive evidence of a long history of amniotes well into the Carboniferous. Unfortunately, the highly modified body shape of turtles makes comparison with other reptile groups difficult. Surprisingly, there are few substantiated turtle tracks of any age reported in the literature, although skeletal remains of turtles have long been known from Upper Jurassic and Upper Triassic lithologies in Western Europe (Joyce 2000).

Based on the typical anapsid skull of cotylosaurs, the diminutive reptile Eunotosaurus africanus from the middle Permian of South Africa provides an important link to the mysterious origin of turtles (Colbert 1980). Recent phylogenetic analysis (Hancox and Rubidge 2000) focussed on this enigmatic reptile, identifies Eunotosaurus as procolophonid sister group (together with pareiasaurs) of parareptiles, and further as ancestral to anapsids (Reisz and Laurin 1991; Gow and Rubidge 1997). Early Permian procolophons are also well represented in the Maritimes (Mossman and Place 1989; Calder et al. 1995; van Allen et al. 2005) although nothing recognizable as strictly turtle-like.

Reasoning from cladistic analysis, Rieppel and deBraga (1996) have drawn attention to the diapsid affinities of turtles, with the implications that, as a reptilian subclass of "parareptiles", turtles emerged in the Triassic. A complex computer-driven reappraisal of turtle relationships subsequently undertaken by Rieppel and Reisz (1999) provides some support for this maverick theory. However, it should be pointed out that this work might equally be said to exacerbate the predicament of deciding which characteristics are most suitable to employ in the (computer) analysis. Reportedly, the ankles of turtles are the main factor that convinced Riepell and co-workers that turtles are diapsids (Garcia 1997, p. 24). Further, given that minor tweaking of characteristics in the data matrix moves turtles back into anapsids can scarcely stand as a recommendation for this idea. As Wilkinson et al. (1997) have pointed out, given the absence of a temportal opening (the defining characteristic of anapsids), the traditional relationship of turtles with anapsids could still be correct. In proceeding now to document a new turtle-like trackway from Early Carboniferous strata at Horton Bluff, we assume that this is indeed the case. 


\section{NEWLY DISCOVERED TRACKWAY}

The turtle-like trackway (Fig. 3) was discovered in an area along the north shore of the Blue Beach fault near Horton Bluff. The host sediments belong to the Blue Beach Member of the Horton Bluff Formation. The rock is a micritic siltstone, the upper several millimetres-thick layer of which contains the footprints as positive impressions. At the same stratigraphic horizon several metres distant, another three interlocking slabs of rock were collected, two of which bear footprints of a trackway of Peratodactylopus bishopi ichnogen. et ichnosp. nov. an ichonogenus described from this same general locality at Horton Bluff by Sarjeant and Mossman (1978a; 1978b).

Systematic Description

Reptilia
Cotylosauria Cope
Captorhinomorpha Watson
Eochelysipus ichnosp. nov.
(Figs. 3, 4, and 5)

Derivation of name: Greek, Eos, dawn; chelys, turtle; pus, foot: with reference to the earliest turtle-like track.

Diagnosis: Quadrupedal tracks showing moderate stride, and sprawling gait. Pace varies slightly in length, generally exceeding track breadth; stride length to pes length ratio ranges from 4.3 to 5.3. Manus and pes impressions show the front part of the palm and the digits firmly impressed (Fig. 4) and oriented more or less anteriorly. Pes pentadactyl, manus poorly preserved but apparently tetradactyl with all digits directed forwards. Width of manus approximately equal to the length. Pes is slightly larger than manus; Front portion of the soles of both manus and pes are more deeply impressed than the back portions. Raised rims to the footprints. Impressions strongly digitigrade; digits moderately long and slim, and with pointed claws. Digits of the pes show phalangeal pads more clearly than those of the manus and all are clawed (Fig. 5). Digits on manus and on pes are directed outwards, although digit I of each is almost directed forward. The two outermost digits are shortest.

Type ichnopecies: Eochelysipus horni ichnogen et ichnosp. nov., Horton Bluff Formation (Mississippian), Nova Scotia, Canada.

Remarks: The presence of phalangeal pads and claws on the digits are two of the main features which show that these tracks are those of an early reptile. A third feature is the location of the palm proxero-laterally behind digits III-IV. There is a faint tail drag, best developed between the first four footprints (Fig.

Fig. 3 Eochelysipus horni ichnogen. et sp. nov. Portion of holotype showing seven opposing pairs of footprints. Oblique lighting from right. Scale in centimetres.

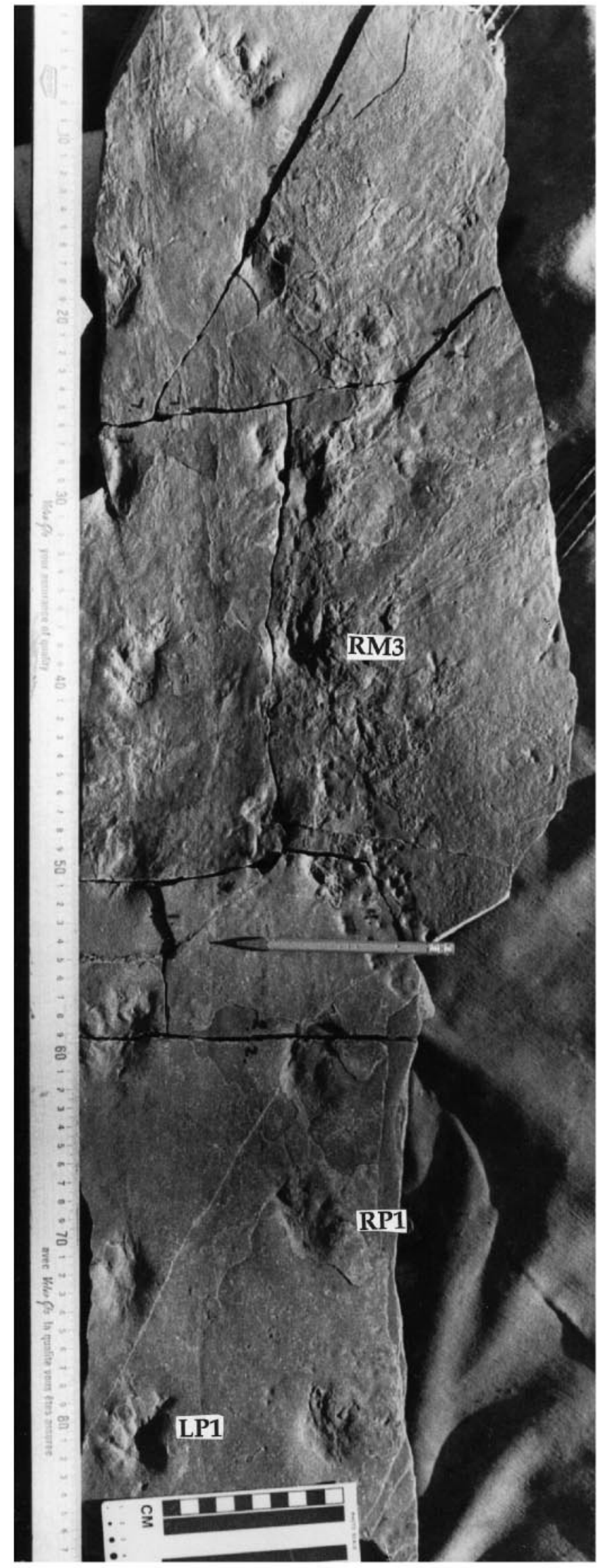




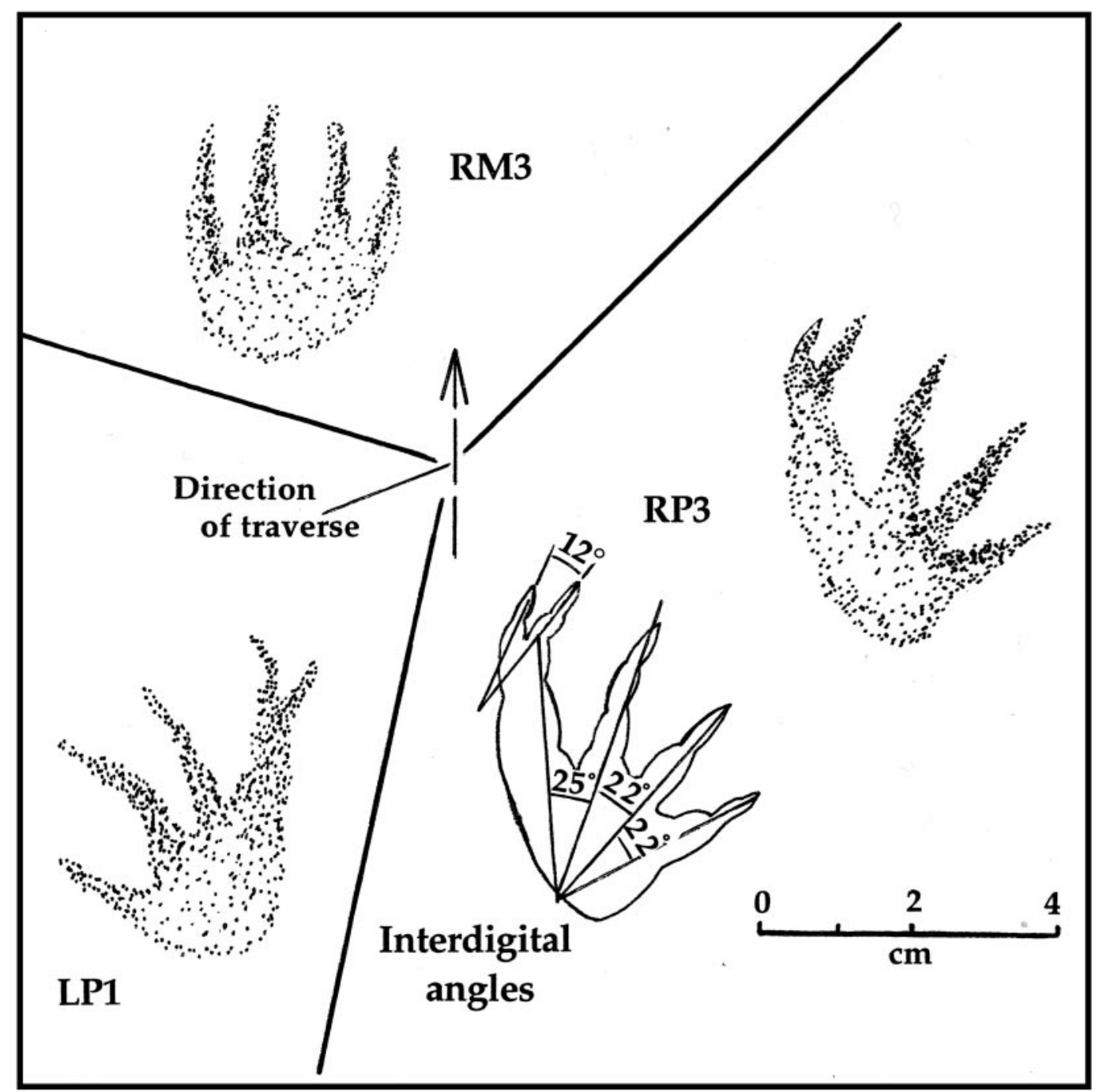

Fig. 4 Eochelysipus horni ichnogen. et sp. nov. Interpretive drawing of LP1, RP3, and RM3. Sketch to show interdigital angles on RP3. Scale in centimetres applies to all footprints.

3), and a possible indication of body (shell?) drag from prints 5 and 6 through to the end of the trackway. Field observations of turtles (Fig. 6) show, however, that although the crucial element in all turtle trackways may be said to be shell drag, this feature is not necessarily registered even with passage of a turtle over fresh moist mud. Conspicuous also in our experimental trackways with an adult Eastern painted turtle are deep claw marks, forwardly directed drag marks, and slightly wider separation from the midline of the trackway of the pes compared to that of the manus. Given the very wide trackway and the low pace angle $\left(<90^{\circ}\right)$, the elongate digital scrape marks left by the trackmaker indicate a turtle-like creature walking under terrestrial conditions.

Quite apart from the big difference in size of footprints and trackways, the evidence of claws and phalangeal pads in Eochelysipus rules out strict comparison with such (temnospondyl ?) ichnospecies as Palaeosauropus primaevus and Palaeosauropus ichnosp. Then, comparisons of cotylo- saur-like Amphisauropus and Peratodactylopus bishopi with Eochelysipus fail because of the large size of their individual footprints/trackways, their totally different gaits, and because of their relatively narrow trackways. Like turtle trackways, the trackway of Eochelysipus is very wide relative to the small size of individual footprints. Recall that Peratodactylopus occurs at the same locality and stratigraphic interval as Eochelysipus; however, it is not unusual to find two different types of reptiles occupying the same ground as, for example, along the shores of certain islands in the Galapagos.

Disregarding, for the sake of argument, the identity (as pes or manus) of its individual footprint impressions, a turtle trackway approaches the picture of near mirror image-like symmetry across the midline of a very wide trackway. In consequence, the individual footprints appear relatively small compared to the width of the trackway. Nor, as is usually the case for a sprawling gait, is inagility otherwise indicated. These general characteristics, as much or perhaps more than any others, stand out as 


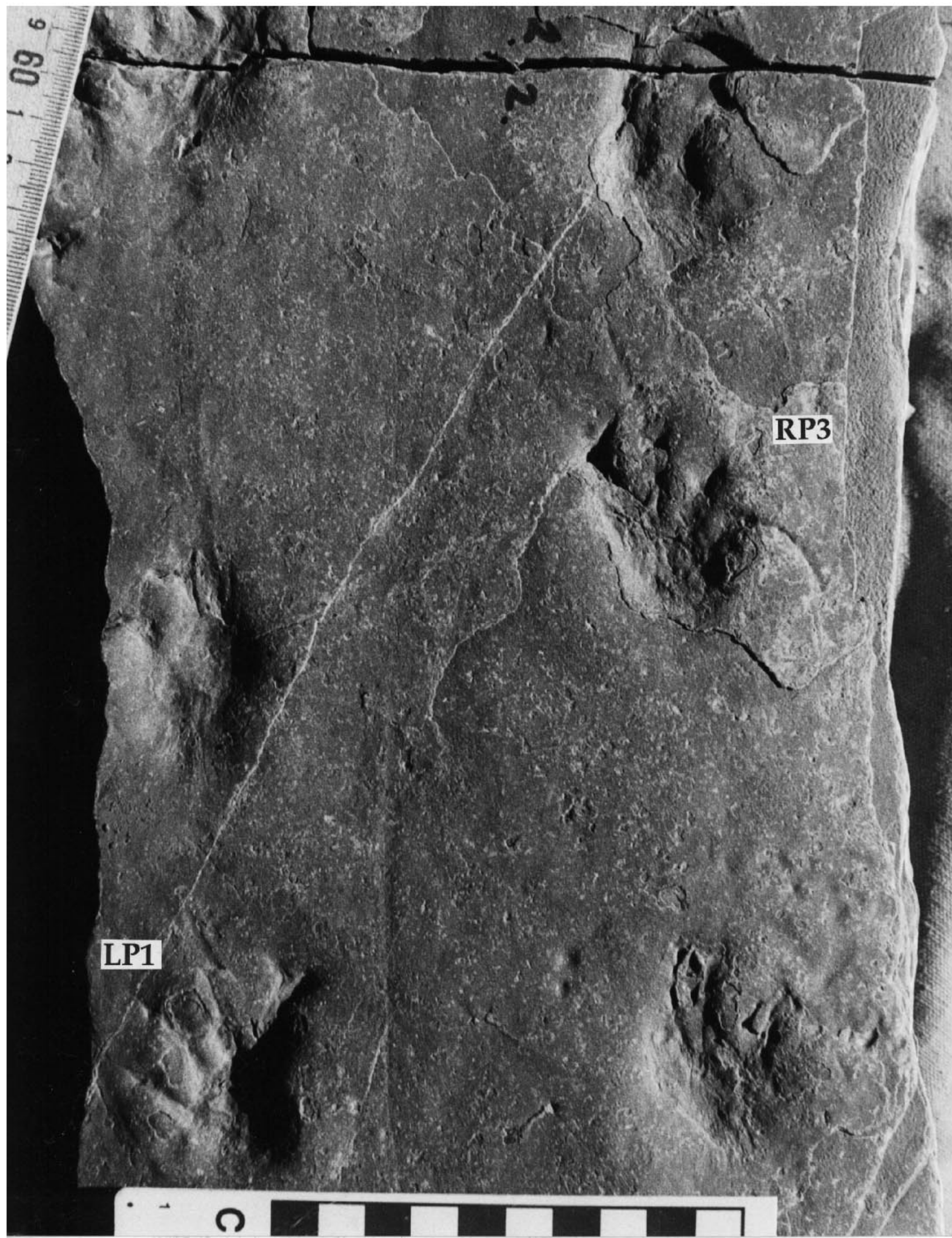

Fig. 5 Close-up of Eochelysipus horni et sp. nov.; compare LP1 and RP3 with interpretive drawing (Fig. 4) of these footprints. Centimetre scale at bottom of photograph. 


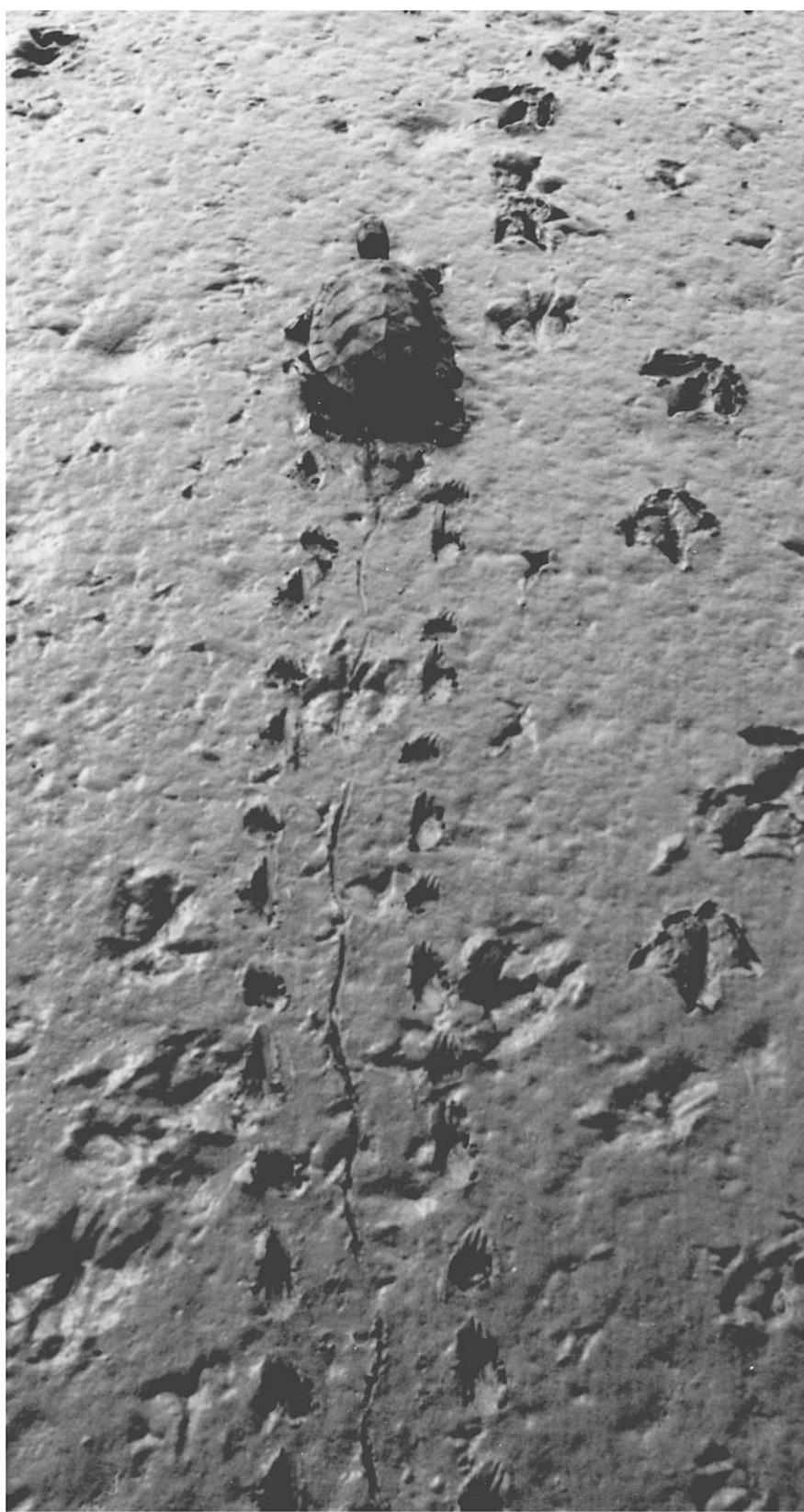

Fig. 6 Adult female Eastern Painted turtle (Chrysemys picta picta) making tracks on the freshly exposed surface of a Bay of Fundy tidal mudflat. Width of trackway $=12.3$ $\mathrm{cm}$. Note: discontinuous tail drag, but little evidence of shell drag; hole drilled at edge of shell above right pes. Other footprints are those of seagulls.

distinguishing features of turtles. They are also conspicuous characteristics of Eochelysipus horni. A possible pelycosaur trackway from the Westphalian A, Germany (Haubold 1984, p. 66, Fig. 42), could be said to closely resemble Eochelysipus except for the fact that the width of the trackway falls far short of a turtle-like trackway. As explained below, Emydhipus, a bona fide turtle track from Late Jurassic strata of Asturias, Spain, most closely resembles Eochelysipus.

Avanzini et al. (2005, p. 745) have identified several new tracks left by "... a quadrupedal animal with sharp claws, wide gait, and five-toed hind limbs" as those of turtles. They also include a succinct review of the confused ichnotaxonomy and interpretation of purported turtle tracks, together with their case for renaming Chelonichnium cerinense [named by Demathieu and Gaillard (in Bernier et al. 1982) for a controversial Late Jurassic trackway at Cerin, France] as Emyhipus cerinensis. Further, according to Avanzini et al. (2005, p. 748) "...the abandonment of Chelonichnium (nomen dubium) requests a new attribution for Chelonichnium cerinense; a track certainly attributable to a turtle." Consequently, Avanzini et al. (ibid.) explain that Emydhipus cerinensis is one of only two ichnogenera attributed to turtles that are currently valid. The other is Chelonipus Rühle von Lilienstern, 1939, a walking turtle track from the Lower Triassic.

Emydhipus cerinensis revisited, resembles Eochelysipus horni in its wide gait, and in having manual prints slightly internal to the pedal ones, and without overpass. With a trackway width of $7.3 \mathrm{~cm}$, Emydhipus cerinensis is evidently the work of a much smaller animal, although strict comparison is handicapped by the fact that one trackway $(C$. cerinensis) was probably made by a swimming (bottom walking) creature in a shallow water environment, whereas the other is a terrestrial trackway (Avanzini et al. 2005). Consequently Emydhipus cerinensis lacks certain definition, being characterized by pronounced scratch marks [reminiscent of the widespread occurrence of scratch marks in the shales at Blue Beach, Horton Bluff, made by clawed appendages of unidentified creatures (Sarjeant and Mossman 1978a)].

Derivation of ichnospecies name: After Stephen Horne, discoverer of the Eochelysipus and who subsequently helped extract the holotype and donated it to the Nova Scotia Museum of Natural History in Halifax.

Holotype: Specimen NSM 995GF.077a, housed in the Nova Scotia Museum of Natural History, Halifax, Nova Scotia, in seven contiguous pieces, altogether showing four left manus and four right manus, and three left pes and three right pes imprints.

Type horizon and locality: Base of Bell's (1960) unit b2, Horton Bluff Formation, Horton Bluff (Lower Mississippian: Tournaisian), $2.5 \mathrm{~km}$ southeast of Avonport Station, Nova Scotia.

Dimensions: Width of trackway $14 \mathrm{~cm}$, stride $20 \mathrm{~cm}$, pace 14 $\mathrm{cm}$, step angle $88^{\circ}$ (Fig. 3). Footprints are not all equally wellimpressed; all are somewhat washed out. The measurements here noted are taken from the best impressed footprints (RM2, RP1, LP1, LP2 of Fig.3). Right manus: maximum length (from back of palm to top of digit II, $35 \mathrm{~mm}$ ); maximum span (from tip of digit I to tip of digit IV), $30 \mathrm{~mm}$. Length of digits: I, 14(?) $\mathrm{mm}$; II 16(?) mm; III, 18(?) $\mathrm{mm}$; IV ca.18 mm. Right pes: maximum length, $45 \mathrm{~mm}$; maximum span, $40 \mathrm{~mm}$. Lengths of digits: I, 25 mm; II, 20 mm; III, 18 mm; IV, 10 mm. 
Divarication of digits: Left manus: digits poorly preserved, but approximately parallel, facing forward; right pes: I-II, $12^{\circ}$, II-III, $25^{\circ}$, III-IV, $22^{\circ}$, IV-V, $22^{\circ}$.

\section{ACKNOWLEDGEMENTS}

We thank Stephen Horne for bringing the trackway to our attention, for assisting in recovery of same, and for donating it to the museum. John Calder generously provided constructive criticism of an early draft of the paper but is in no way responsible for any errors of omission or commission therein. Valuable suggestions and criticism provided by journal editor Ron Pickerill and reviewers Philip Currie and Spencer Lucas are gratefully acknowledged.

\section{REFERENCES}

Ahlberg, P.E. And Milner, A.R. 1994. The origin and early diversification of tetrapods. Nature, 368, pp. 507-514.

Avanzini, M., Garcia-Rames, J.C., Lires, J., Menegon, M., PinûELA, L., ANd Fernández, L.A. 2005. Turtle tracks from the Late Jurassic of Asturias, Spain. Acta Palaeontologia Polonica, 50, pp. 743-755.

BELL, W.A. 1960. Mississippian Horton Group of type Windsor-Horton district, Nova Scotia. Geological Survey of Canada, Memoir 314, 58 p.

Bernier, P., Barale, G., Bourseau, J.P., Buffetaut, E., Demathieu, G., Gaillard, C., and Gall, J.C. 1982. Trace nouvelle de locomotion de chelonian et figures d'emersion associées dans les calcaires lithographiques de Cerin (Kimméridgien supérieur, Ain, France) Geobios, 15, pp. 447-467.

Calder, J.H. 1998. The Carboniferous evolution of Nova Scotia. In Lyell: The Past is a Key to the Present. Edited by D.J. Blundell and A.C. Scott. Geological Society of London, Special Publication 143, pp. 261-302.

Calder, J.H., van Allen, H.E.K., Adams, K.G., and Grantham, R.G. 1995. Tetrapod trackways in a fossil Walchia forest: a new discovery from the early Permian of Nova Scotia. Atlantic Geology, 31, p. 42.

Clack, J.A. AND CARroll, R.L. 2000. Early Carboniferous tetrapods. In Amphibian Biology, vol. 4. Edited by H. Heatwole and R.L. Carroll. Palaeontology, Chipping Norton, New South Wales, Australia, Surrey Beatty, pp. 1030-1043.

Colbert, E.H. 1980. Evolution of the vertebrates, $3^{\text {rd }}$ edition. Wiley Interscience, New York. 510 p.

Crosby, D.G. 1962. Wolfville map area, Nova Scotia (21H1). Geological Survey of Canada, Memoir 325, 67 p.

Daeschler, E.B., Shubin, N.H., Thomson, K.S., ANd AmaRAL, W.W. 1994. A Devonian tetrapod from North America Science, 265, pp. 639-642.

Garcia, E. 1997. Where do turtles go? Scientific American (News and Analysis), 276, pp. 24-25.
Gesner, A. 1836. Remarks on the Geology and Mineralogy of Nova Scotia. Printed by Gossip and Coade, Times Office, Halifax, pp. 10-11.

Gow, C.E. And Rubidge, B.S. 1997. The oldest procolophonoid (amniota: parareptilia) - new discovery from the lower Beaufort of South Africa. Palaeontology of Africa, 34, pp. 49-53.

Hancox, P.J. And Rubidge, B.S. 2000. Breakthroughs in the biodiversity, biogeography, biostratigraphy, and basin analysis of the Beaufort Group, African Earth Sciences, 33, pp. 563-577.

HaUbold, H. 1984. Saurierfährten. Die Neue Brehm-Bücherei, A. Ziemsen Verlag. Wittenberg Lutherstadt, $231 \mathrm{p}$.

Martel, A.T. ANd Gibling, M.R. 1996. Stratigraphy and tectonic history of the Upper Devonian to Lower Carboniferous Horton Bluff Formation, Nova Scotia, Canada. Atlantic Geology, 32, pp. 13-38.

Martel, A.T., Mcgregor, D.C., and Utting, J. 1993. Stratigraphic significance of Upper Devonian and Lower Carboniferous miospores from the type area of Horton Group, Nova Scotia, Canadian Journal of Earth Sciences, 30, pp. 1091-1098.

Mossman, D.J. and Place, C.H. 1989. Early Permian fossil vertebrate footprints and their stratigraphic setting in megacyclic sequence II red beds, Prim Point, Prince Edward Island. Canadian Journal of Earth Sciences, 26, pp. 591-605.

Mossman, D.J. and Sarjeant, W.A.S. 1980. How we found Canada's oldest footprints. Canadian Geographic, October/ November, 100 , pp. 50-53.

Orenstein, R. 2001. Turtles, Tortoises and Terrapins: Survivors in armour. Firefly Books, Buffalo New York, 308 p.

REISZ, R.R. 1997. The origin and early evolutionary history of amniotes. Trends in Ecology and Evolution, 12, pp. 218-222.

ReISZ, R.R. AND LAURIN, M. 1991. Owenetta and the origin of turtles. Nature, 349, pp. 324-326.

Rieppel, O. AND REISz, R.R. 1999. The origin and evolution of turtles. Annual Review of Ecological Systems. 30, pp.1-22.

Rieppel, O. and Debragga, M. 1996. Turtles as diapsid reptiles. Nature, 384, pp. 453-455.

SarJeant, W.A.S. and Mossman, D.J. 1978a. Vertebrate footprints from the Carboniferous sediments of Nova Scotia: a historical review and description of newly discovered forms. Palaeogeography, Palaeoclimatology, Palaeoecology, 23, pp. 279-306.

Sarjeant, W.A.S. and Mossman, D.J. 1978b. Peratodactylopus, new name for the vertebrate footprint ichnogenus Anticheiropus. Sarjeant and Mossman, Non Hitchcock, 1965. Journal of Palaeontology, 52, pp. 1102.

Tibert, N.E. AND Scott, D.B. 1995. A palaeoecological interpretation of the ostracodes from lagoonal/lacustrine late Devonian/ early Carboniferous Horton Bluff Formation, Nova Scotia, Canada. Abstract in International Paleo- 
oceanography Conference, Halifax, Nova Scotia, October 1995, p. 96.

van Allen, H.E.K., Calder, J.H., And Hunt, A.P. 2005. The trackway record of a tetrapod community in a Walchian conifer forest from the Permo-Carboniferous of Nova Scotia. In The Non-Marine Permian. Edited by S.J. Lucas and K.E.
Zeigler. New Mexico Museum of Natural History and Science, Bulletin 30, pp. 322-332.

Warren, A., Jupp, R., ANd Bolton, B. 1986. Earliest tetrapod trackway. Alcheringa, 10, pp. 183-186.

Wilkinson, M., Thorley, J., And Benton, M.J. 1997. Uncertain turtle relationships. Nature, 387, pp. 466.

Editorial responsibility: Ron K. Pickerill 